\title{
ABOUT HISTORICAL REASONS FOR CONTEMPORARY SLOVENE DISSATISFACTION WITH SLOVENE POSTSOCIALIST REPRESENTATIVE DEMOCRACY
}

\begin{abstract}
The text presents an analysis of historical reasons for contemporary Slovene dissatisfaction with Slovene postsocialist representative democracy. The core reason for this dissatisfaction lies in the fact that Western democracy differs in many characteristics from native Slovene democracy, which was an important part of Slovene social organization from the $6^{\text {th }}$ century to the end of socialism. The analysis will present Slovene native democracy and its most important characteristics and compare these with the characteristics of imported Western democracy. The analysis proves that imported Western democracy transgresses the most important practices and characteristics of Slovene political heritage which are from a native Slovene perspective, connected, even equated with democracy. This produces several problems, including dissatisfaction with Slovene postsocialist democracy. In the text historical analysis and data collected through field work in Slovene postsocialist society will be combined.
\end{abstract}

Key words: democracy, direct democracy, Western democracy, postsocialism, Slovenia.

\section{Introduction: About Slovene dissatisfaction with postsocialist democracy}

After more than 25 years of Slovene postsocialism, one of the key characteristic of Slovene postsocialist society is the fact, that Slovenes are not satisfied with their experience of post-socialism. Slovene citizens are not satisfied with Slovene postsocialism in general, and with Slovene postsocialist representative democracy in particular. The public opinion research reported that $3 / 4$ of Slovenes are not satisfied with post-socialist Slovenia (Caharijas 2016: 1) and the Slovene national study Politbarometer reported that 87 percent of Slovenes are not satisfied with the functioning of Slovene democracy (Center za proučevanje javnega mnenja 2013, 2014). In the last decade, Slovene dissatisfaction with democracy increased by more than 20 percent in just three years- in 2010 this dissatisfaction was at around 60 percent, and in 2013/2014 increased on 87 percent (Center za proučevanje javnega mnenja2013; 2014).

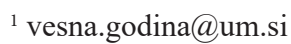


This dissatisfaction can be understood and explained in multiple ways. However, it is important to notice that in the year 2016 official Slovene politics celebrate 25 years of an independent, post-socialist Slovene state. This celebration was accompanied by several falsifications of Slovene history and by uncritical glorification of Slovene postsocialism, under which the lives of the majority of Slovenes changed in one or more aspects for the worse. Thousands of people lost their jobs and became unemployed for the first time in their lives; thousands experienced poverty, the inability to buy food and other basic goods for their families and children; they experienced social death. Those who remained employed, lived in permanent anxiety about losing their jobs. They were also excluded from decision making processes in the firms where they worked - contrary to self-management, which was the normal organisation in firms during socialism.

Opinions, collected through my field work ${ }^{2}$, are in accordance with these results. An unemployed worker commented: "There is no democracy in this state" (Field material, unemployed worker, November 2009). A retired female worker agrees: "This parliament supposed to be a democracy? This is a waste of money, not a democracy" (Field material, retired clerk, July 2010). Or: "Maybe somewhere this democracy functions...Perhaps in the West. But here this is not a democracy" (Field material, retired male worker, September 2010).

Slovene dissatisfaction with post-socialism and Western democracy ${ }^{3}$ is the result of a complex interplay among several factors. One of these is nostalgia for socialism. ${ }^{4}$ Another is the social construction of mistrust (see Giordano \& Kostova 2007), which occurs when "a state repeatedly fails to perform its fundamental duties, particularly the responsibility of creating the conditions to guarantee a "pacified space', in which they /citizens - VVG/ can trust each other through the 'rule of law"" (2007: 75). Such a failure is common in Slovene post-socialism. ${ }^{5}$

\footnotetext{
${ }^{2}$ I have been collecting data about Slovene post-socialism since 2005 with participant observation (see Burges 1990: 78-101), semi-structured interviews and interviews as conversations (1990: 101-123) and analysis of documents and texts. Qualitative research has been done in accordance with standards for participant observation in social and cultural anthropology (see Burgess 1990).

${ }^{3}$ In the text, the term 'Western democracy' is used as it is used in the native Slovene understanding of democracy, namely as a synonym for the Western type of multi-party parliamentary democracy. Most Slovenes and Slovene politicians use the term 'Western democracy' as if there existed only one type of Western democracy. In this understanding, differences between several-variants of democracy in different Western states are ignored.

${ }^{4}$ As anthropologists of postsocialism have established, nostalgia for socialism is in fact nostalgia "for an age when they (people - VVG) had fewer and less secure rights in a legal sense, yet their needs were more adequately fulfilled than is the case a decade later" (Hann 2007: 11). Hann and Hart stress that this nostalgia does not mean that people would prefer to live in the old version of socialism if they could, but that it should be understood as a form of resistance: in their opinion, nostalgia reflects resistance to the dominance of new elites and Western products and resistance to neoliberal capitalism (Hann \& Hart: 132-133). This resistance expresses itself in various everyday practices (Berdahl 1997; 1999; Velikonja 2008). This nostalgia has been documented also for Slovenia and other post-Yugoslavia states; in this region it takes the form of Titostalgia (Velikonja 2008), i.e. nostalgia for Josip Broz Tito, the President of the Socialist Federal Republic of Yugoslavia, who symbolises life in socialist Yugoslavia (see Adrić, Arsenijević \& Matić 2000) and of Yugostalgia (nostalgia for former socialist Yugoslavia).
}

${ }^{5}$ Social production of mistrust has become a regular practice in most postsocialist countries. Giordano 
However, I will analyse dissatisfaction with Western democracy in post-socialist Slovenia as a result of the fact that, in Slovene post-socialism, local history and local culture have been ignored. This mistake, regularly made in post-socialist societies, has been extensively analysed by anthropologists of post-socialism (see Abrahams 1996; Berdahl 1997, 1999; Bridger \& Pine 1998; Giordano \& Kostova 2007; Godina 2016; Humphrey 1998, 2002, 2007; Lampland 2007; Hann 2007; Kalb 2007; Kaneff 1996, 2002; Kideckel 1999, 2007, 2008; Pine 2007; Verdery 1993, 1996, 1999, 2007). These scholars prove that ignorance of local history and culture always produces complex problems, because it ignores several aspects of social reality. One is ignorance of the fact that "institutions are peopled by local actors" (Lamplaned 2007: 32), which means that in post-socialist societies, answers to the question of "how specific cultural understandings shape people's behaviour" (Hann 2007: 8) are ignored. Also ignored is the influence of local history on contemporary behaviour of local actors: "The tendency to dismiss the consequences of local socialist history is problematic ... Socialism was not simply a package of bad economic policies, but a complex social and cultural world in which people lived and worked" (Lampland 2007: 32).

In their analysis of postsocialism, anthropologists of post-socialism develop "a retrospective cultural area argument" (Kalb 2007: 322), which stresses that post-socialist "transformation outcomes cannot be directly explained by transition programmes but have unintended outcomes shaped by prior (socialist) conditions, expectations and division of assets" (2007: 322). Anthropologists of postsocialism "argue for the path-dependence of all transformation outcomes...Dynamic pathdependence helps to explain how and why memories, knowledge and networks from the past are reconfigured in the present to serve as tools for survival or advantage in situated social practices under new conditions" (2007: 322, 323).

In my analysis I will use this dynamic path-dependency logic to explain how and why memories, knowledge and networks from the Slovene past are present in Slovene post-socialism and why these cannot serve as an advantage under new, postsocialist conditions, but instead generate dissatisfaction with Slovene post-socialist democracy. Slovene dissatisfaction with post-socialist democracy is, in my opinion, a specific example of the principle, described by Kiedeckel (2007: 115); in his opinion "the region's problematic is not too slow a movement to capitalism... but too fast; not too little capitalism, but too much".

\section{The most important historical data about native Slovene democracy}

According to historians (see Blaznik, Grafenauer \& Vilfan 1970; Blaznik, Grafenauer \& Vilfan 1980; Maček 2007; Vilfan 1944; 1961), over the course of their

and Kostova stressed (2007: 75) that the social production of mistrust is a system of representations and rational strategies, which "is based on specific practices that necessarily stem from past negative experiences, which are reactivated in the present through the group's collective memory". 
history, Slovenes have developed their own typical form of native direct democracy. They also stress that native Slovene democracy was not an invention of our Slovenes, but was one of the key features of Old-Slavic social organisation before the time of settlement by Slavs on today's Slovene territory (Maček 2007: 43; Vilfan 1961: 27-28; 63). This social organization had already been described by two Byzantine writers in the $6^{\text {th }}$ and $7^{\text {th }}$ century. Vilfan $(1961: 24)$ notes "Prokopios...talks about the democratic way of life among Slavs... who don't have one man for a king, but perform all public affairs collectively".

The social form in which public affairs were performed collectively in OldSlavic society was veča, a special form of meeting or assembly "where members or representatives of broader or narrower community, originally based on decent or tribe community, met together. Democracy on one side, and anarchy and quarrelling on the other side - a situation that was reported by Byzantine writers - this was veča of different communities or their chiefs, from a Byzantine perspective. At veča they accepted conclusions about common matters and probably also decided about conflicts" (1961: 27-28).

Historians claim that the Slavs who moved to contemporary Slovene territory in the 6th century brought this type of Old-Slavic social organization with them (1961: 27-28; Maček 2007: 43). Old-Slovene society - i.e. the society in which Slovenes lived between the 6th and 9th centuries - functioned in accordance with elements of Old-Slavic social organization. ${ }^{6}$

In Old-Slovene society veča remained a meeting or an assembly at which decisions important for the whole community were accepted (Maček 2007: 43; Vilfan 1961: 63). ${ }^{7}$ Veča also remained the most important institution in the decisionmaking process and also the most important form of realization of the authority and power of the Old-Slovene leader, $k n e z .^{8}$

Knez realized his authority and power through meetings of veča. Knez formally headed the meetings of veča (Maček 2007: 44; Vilfan 1961: 63) and participated in the decision-making process, in which he could exert influence through his authority; however, he was not able to accept decisions by himself. He was not superior to veča, but subordinate to it. This means that in Old-Slovene society knez was not a political leader of a political unit (Maček 2007: 44). The only exception was knez in Carantania, who was a political leader of a political unit - Carantania state (Vilfan 1961: 57; Maček 2007: 44). ${ }^{9}$ However, untill the 8th Century, knez in Carantania

${ }^{6}$ The most important historical source for Old-Slovene society is the document Conversio, which dates to 871 (Vilfan 1961: 57).

${ }^{7}$ Vilfan (1961: 66) treats veča as one of the most important survivals of Old-Slavic society in OldSlovene society.

${ }^{8}$ Old-Slovene knez was a type of native Old-Slovene leader, who led and governed a territorial unit of Old-Slovene society, called a kneževina (Vilfan 1961: 57; Maček 2007: 37). This unity was organized on territorial principles, not by descent (Maček 2007: 37; Vilfan 1961: 26, 27, 56). This characteristic distinguished the Old-Slovene knez from the Old-Slavic knez. Despite this difference, historians treat knez as one of the most important survivals of Old-Slavic society in Old-Slovene society (Vilfan 1961: 66).

${ }^{9}$ The state of Carantania was the only example of a political state in Old-Slovene social organization. 
was elected by representatives of the people of Carantania (Maček 2007: 37-39; Vilfan 1961: 57-59; 1980: 291, 321). Later, when the position of Carantania's knez became hereditary, knez had to be confirmed by representatives of the people. The ritual of electing and/or confirming knez by representatives of the people, called ustoličevanje $^{10}$, was practiced till 1414 (Maček 2007: 37-39; Vilfan 1961: 57-59; 1980: 291, 321). Ustoličevanje represents not only one of the most stable survivals of Old-Slovene society in Slovene feudalism, but also one of the most striking examples of the indigenization of feudalism in Slovene feudal society. ${ }^{11}$

In Old-Slovene society, various forms of veča were practiced (Maček 2007: 43; Vilfan 1961: 63). The first type of veča was an electoral veča, i.e. the veča which elected knez (ibid.). The second type of veča was a svobodinska veča, i.e. the veča of free members of Old-Slovene society (Maček 2007: 43; Vilfan 1961: 63) ${ }^{12}$. This veča was "an assembly of all svobodins, who lived župa"13 (Vilfan 1961: 63). This was the most frequent type of veča in Old-Slovene society. This type of veča met for a territory of one župa (known as a župska veča, i.e. župa's veča), or for a group of večas (Maček 2007: 43; Vilfan 1961: 63). For the territory of a whole kneževina, a koseška veča (veča of kosezis) was usual (Maček 2007: 43; Vilfan 1961: 63). ${ }^{14}$

Historians agree that in Old-Slovene society different types of the veča had different types of power: the veča of svobodins and the veča of one župa defined obligatory rules which regulated social life in župa (Maček 2007: 43; Vilfan 1961: 63), which means that this type of veča had special types of public administration

It was located on the northern part of contemporary Slovene territory and on the southeast part of contemporary Austria. Carantania existed from the 7th Century to 820.

${ }^{10}$ For more about ustoličevanje, see Maček 2007: 38; and Vilfan 1961: 57, 58, 66.

${ }^{11}$ For more about the process of indigenization compare Sahlins 1994.

${ }^{12}$ Svobodins were free farmers (the word svobodin comes from the Slovene word svoboda, which means freedom). In Old-Slovene society, svobodins represented the majority of members of the society (Vilfan 1980c: 293). Old-Slovene society did not practice classical slavery. Slaves lived together with their masters within families as family members (1980b: 293). This type of slavery, called patriarchic slavery (1980b: 292), already existed in Old-Slavic society (Maček 2007: 20; Vilfan 1961: 30).

${ }^{13} \mathrm{~A} z \check{u} u p a$ was the basic territorial and social unit of Old-Slovene society (Maček 2007: 35; Vilfan 1961: 30; 53;61). Župa already existed in Old-Slavic society, but not as a territorial unit, but as a descent unit (Grafenauer 1970: 248; Maček 2007: 22; Vilfan 1961: 52, 59; Vilfan 1980a: 30).

${ }^{14} \mathrm{~A}$ koseška veča was a special type of veča, whose members were kosezi. Kosezi were a special social group in Old-Slavic society, with a special position and duties (Maček 2007: 36, 43; Vilfan 1944: 239; Vilfan 1961: 55-56, 60, 109, 135; 1980a: 59; 1980b: 96; 1980c: 289, 291, 292, 299, 321). They were free farmers with military obligations to the knez (Vilfan 1961: 55; 1980c: 289). A kosez was "partially a farmer, partially and first of all a soldier" (1980c: 299). This last obligation marked them as different from svobodins. They had a special social position and some public functions; they were attendants of the knez (1961: 64); in Carantania they elected the knez; they had their own separate courts etc. (1961: 55; Vilfan 1980a: 59; 1980c: 291; Maček 2007: 36, 39). They lived separate from the other inhabitants of Old-Slovene society in their own župas, called koseške župe (2007: 36, 43; Vilfan 1961: 55-56; 1980c: 320). Their communities represent a special form of agrarian autonomy (Vilfan 1980a: 59). Kosezis veča was the only known element of representative democracy in Old-Slovene social orgaization. 
duties, power and authority (Maček 2007: 43; Vilfan 1961: 63). The večas of broader teritories (i.e. the veča for more župas and kosezi's veča) accepted obligatory decisions for a wider region of several župas or for a whole kneževina. These večas had special types of legislative duties, power and authority (Maček 2007: 43; Vilfan 1961: 63). Historians agree that večas also exercised court authority in Old-Slovene society (Maček 2007: 43; Vilfan 1961: 63). All večas always met in the open (Maček 2007: 43; Vilfan 1961: 63).

As the longest period of Slovene history (from 820 to 1848$)^{15}$, feudalism introduced a special type of Slovene feudal social organization. One characteristic of that organization was the indigenization of Western feudalism in Slovenia. German feudalism was adopted and adapted in accordance with Old-Slovene society and its characteristics (Vilfan 1961: 66). The introduction of feudalism on the territory of today's Slovenia was a complex proces of social change ${ }^{16}$, in which many characteristics of Old-Slovene society survived and continued to exist and function in Slovene feudal society. This was why many characteristic of Old-Slovene society persisted in Slovene feudal society. One of these was veča. As a special form of native Slovene direct democracy veča remainded a part of Slovene society under feudalism.

However, veča in Slovene feudalism changed some of its charactetristics. For example, members of veča were no longer free farmers, svobodins, but members of distinctive social gropus. Veča in Slovene feudalism was "an assembly of individuals who formed not only a distinctive territorial, but also state, professional or any other community with special interests. When a new community arose...a new type of veča was also formed"(Vilfan 1961: 87-88). This means that under Slovene feudalism, večas were connected with a new feudal social stratification; different types of the večas were a manifestation of that stratification and an institutional form of it. This is why veča was not repudiated by Slovene feudalism (Vilfan 1961: 8788). Even more, Slovene feudalism needed veča as a form of social control of people and different social groups (1961: 87-88). This was also why večas were introduced in towns (Maček 2007: 43-44; Vilfan 1961: 63).

Another important reason why veča remained a part of Slovene feudal society was that veča was such an important social practice for Slovenes that the new feudal state had to accept it in order to avoid socal conflict (1961: 88). And it was accepted. Večas, with many of their typical practices remained an important part of Slovene feudal society till the end of feudalism, i.e. till 1848 .

In Slovene feudalism, večas remained "organs of autonomy and selfgovernment"(1961: 87). As organs of autonomy, večas adopted rules for the concrete

\footnotetext{
${ }^{15}$ In the year 820, Carantania, the only Old-Slovene state lost its independence (Maček 2007: 31; Vilfan 1961: 50); in 1848 the liberation of peasant holdings from feudal obligations represented the end of feudalism in Slovenia (2007: 262-263).

${ }^{16}$ This is also why the introduction of feudalism on today's Slovene territory was a slow process (Maček 2007: 56; Vilfan 1961: 96-97). It took approximately 250 years for the small Slovene territory to accept Western feudalism (Maček 2007: 56); feudalism was introduced across Slovene territory only in the 11th Century and became a dominant and stable social organization between the 13th and the 14th Century (2007: 99).
} 
social community $(1961 ; 87)$; as organs of self-government, they were in charge of implementing these rules (1961: 87). Večas continued to perform "administrative, legislative and juridical activities" (1961: 87), characteristic of their activities in OldSlovene society. What is more, in Slovene feudalism these večas always met in the open (1961: 63; Maček 2007: 43), not only in villages, but also in towns (Maček 2007: 43-44; Vilfan 1961: 63). Only decisions accepted by veča which had met in the open, were understood as binding (Maček 2007: 44; Vilfan 1961: 63). The only modification of this rule was the later principle that veča could meet in an open arbour (Maček 2007: 44; Vilfan 1961: 63).

The majority of members of Slovene feudal society practiced veča in villages as feudal serfs, tlačani. That is why village večas were the most important form of Slovene native direct democracy, in addition to Slovene feudal autonomy and selfgovernment. A feudal Slovene village practiced its self-government in the form of $v e \check{c} a$, which met formally at least once a year, which is evident in the special tribute, called večnina, which was paid to landlords on the occasion of the formal veča's meeting (Maček 2007: 168).

However, formal meetings of veča were not the only form of direct democracy practiced in Slovene feudal villages. Tlačani had to practice autonomy and selfgovernment in a more regular and permanent fashion. What made that necessary was the special organization of land under Slovene feudalism.

Under Slovene feudalism, the land of feudal serfs was organized into Slavic hubas. ${ }^{17}$ In accordance with the strong egalitarianism characteristic of Old-Slovene society $^{18}$, Slovene hubas were organised by markedly egalitarian principles: each serf got not only the same sized huba, but also an identically composed huba (Blaznik 1970: 191; Grafenauer 1970: 240; Maček 2007: 85; Vilfan 1961: 228-229). ${ }^{19}$ This means that the huba of a particular serf was composed from the same proportion of forest, pasture,

\footnotetext{
${ }^{17} \mathrm{Huba}$ is an old name for a serf's farm. In feudalism a huba was a property large enough to feed one serf's family. Its size depended on the percentage of land suitable for cultivation in the area, and usually ranged between 15 and 20 hectares. It also represented a unit of taxation (Maček 2007: 297-298). For Slovenes, the Slavic huba was characteristic. Its size was, according to historians, around 12 hectares (see Blaznik, Grafenauer, Vilfan 1970).

${ }^{18}$ Old-Slovene society was an egalitarian type of society, with very small differences between members. The basic reason for such egalitarianism lay in the fact that Old-Slovene society did not recognize private ownership of the land. Land was under the collective ownership of the župa, in which famlies cultivated as much land as necessary for their survival (Maček 2007: 34, 64; Vilfan 1961: 53). Historians locate the beginnings of private ownership of the land in the 10th century, i.e. in the process of feudalization of Slovene territory (Maček 2007: 34). Prolongation of the egalitarianism of Old-Slovene society into feudal society was one of the most important form of indigenization of Western feudalism in Slovene feudalism. Prolongation of the egalitarianism of Old-Slovene society into feudal society was one of the most important form of indigenization of Western feudalism in Slovene feudalism.

${ }_{19}$ The only exceptions to this priciple were the leaders of župas, called župani, who received double $h u b a$, free of taxes (Maček 2007: 63). This type of huba in Slovene social organization was recognized as an "extreme privilege" (2007: 63). Double hubas were given to župans by landlords as a recompense for their help in the process of feudalization, i.e. for their help in the reorganization of Old-Slovene župas into feudal huba villages (2007: 63-64). Strong egalitarianism was one of those features by which Slovene feudalism can be distinguished from those known in other parts of Europe.
} 
fields and other types of land as the hubas of other serfs. Since the Slovene region is very diverse, this meant that the parcels of land held by each vassal were fragmented by location because they lay in different parts of the village community or seigneury. ${ }^{20} \mathrm{On}$ the same location, the land of several serfs was organized in accordance with the type of land; all fields together, all forest together, all pasture together etc. (Maček 2007: 86). There were no fences or paths between parcels belonging to individual serfs (2007: 86), which meant that an individual could not approach his bit of property without stepping on the land and crop of somebody else (2007: 86; Grafenauer 1970: 248). Therefore, the members of a village community had to agree on when they would - simultaneously perform the same work on the land (1970: 248). This was the only method that allowed cultivation of one's land without destroying the crops of others. To achieve this type of agreement, direct democracy was practiced in the village community.

It was thus cultivation of the land which was the "bases of village economic management... The body responsible for this management was an assembly of all farms owners in a village, leaded by župan of the village" (1970: 248; also Vilfan 1980a: 10, 36). This management included village autonomy and village selfgovernment, which were first of all economic; both were used to organize cultivation of the land in the village community. This type of self-government represents "the most important type of self-government of Slovene farmers in history" (Vilfan 1944: 222). That was true also for the 18th century (1980: 50).

Democracy in village communities was also used by landlords: when they wanted to arrange afairs, landlords organized assemblies at the higher levels of social organization, for example in offices (1980: 50).

This village autonomy and self-government survived the end of feudalism after 1848 (Vilfan 1980a: 53). It continued to function at the village level in various forms of village autonomy and self-government, and continued to be the key feature of Slovene social organisation even during self-management under socialism. Socialism, therefore, did not invent direct democracy but merely proceeded on the essential elements of the Slovene socio-cultural path, established through a 1400year history of direct democracy.

In socialist Yugoslavia direct democracy represented a formal political system, called the "system of socialist self-management" (Kardelj 1977). It was introduced in socialist Yugoslavia in 1953 (Đorđević 1966: 233). The creator of socialist selfmanagement was the Slovene, Edvard Kardelj. ${ }^{21} \mathrm{He}$ transferred traditional Slovene village social organisation into the formal political system of socialist Yugoslavia.

The basic idea of Yugoslav self-management was to guarantee all individuals the chance to decide about all aspects of their lives. As Kardelj (1977:112) stressed,

\footnotetext{
${ }^{20}$ Hence the fragmented land tenure, which is till today a key feature of Slovene agriculture (Maček 2007: 287).

${ }^{21}$ Edvard Kardelj (1910-1979) was one of the closest collaboraters of Josip Broz Tito and the most important author of Yougoslav socialist ideology (Pirjevec 2011: 373-469). He discussed all most important characteristics and problems of Yugoslav socialism (see Kardelj 1955, 1957), he wrote all four Yugoslav contitutions and he elaborated all basic principles of Yugoslav socialist self-management (see Kardelj 1977, 1980).
} 
the essence of Yugoslav self-management was "decision making about personal, common and general social interests".

Self-management as a process of socialist democracy was practiced in all forms and levels of individual and social life. The most important sites for practicing selfmanagement were factories and other organizations where people worked, and local communities where people lived. On those basic levels, all workers and inhabitants participated in the decision-making process in a form of direct democracy (see Kardelj 1977, 1980). On those levels there was no representative democracy, and each individual had the same power (one vote) when participating in decision-making processes. This type of participation in decision-making processes was understood in socialist self-management not only as "unalienable and untouchable right of all working people and members of the community" (Kardelj 1977: 112), but also as a basic social obligation of every inhabitant of socialist Yugoslavia (1977: 112).

At the higher level of social organization, self-management was organized with elements of representative democracy (1977: 145-175; Đorđević 1966: 153154). A representative of people from factories and local communities (called baza, i.e. bases) at the higher levels of decision making process was a delegat (i.e., a delegate). Delegates were organized into groups of delegates, called delegacija. The political system of decision making, based on delegates and delegations, was called delegatski sistem (i.e., delegate system). The delegate system was understood as "a form of self-management and democratic social integration, which was able to express contemporary interests and needs of man, diverse group interests and society as a whole" (Kardelj 1977: 146). It was understood as a form of representative democracy (Đorđević 1966: 153).

A delegate was elected by baza, responsible to his or her $b a z a$, and the people who elected him/her were able to end his/her representative position if the delegate, in their opinion, had not successfully represented their interests. Kardelj (1977: 153) wrote, "delegacija must be connected with its elective bases... it must inform its bases regularly about delegation activities and problems...A delegation is responsible to its elective bases and its self-management community for its work, and through this always exchangeable". Thus, delegates and the delegate system were supposed to be subordinate to the $b a z a$, i.e. to the workers and inhabitants of socialist Yugoslavia. ${ }^{22}$

\footnotetext{
${ }^{22}$ However, it would be wrong to clonclude from description above that socialist Yugoslavia was a kind of democratic El Dorado. There were several reasons for that fact: first, socialist Yugoslavia had one-party political system in which the Communist Party of Yugoslavia had a ruling position; second, Party in many aspects practiced ideological control; third, in socialist Yugoslavia a political elite was established, which was largely untouchable; fourth, in practical realization of self-management several practices that were not in accordance with basic principles of Yugoslav self-management became part of everyday life in socialist Yugoslavia; and fifth, self-management was ineffecitve in many situations. In socialist Yugoslavia, leftist student movements and educated individuals criticized Yugoslavia for such elements, by protesting during ' 68 and demanding more leftist democracy in Yugoslav society. Despite all problems, Flere and Klanjšek (2019:101) described Yugoslav self-management as "Yugoslav innovation that loosened the regime". For more about socialist Yugoslavia and its self-management compare: Allcock, Horton \& Milivojevic 1992; Banac 1984; Bilanžić 1985; Bowman 1993; Burg 1983; Cohen 1995; Dedijer, Božič, Čirković \& Ekmečić 1972; Flere \& Klanjšek 2014, 2017, 2019a, 2019b;
} 
Self-management was practiced as the formal political system of socialist Yugoslavia until the collapse of the state in 1991. Its different forms and practices of direct democracy ended with the disintegration of socialist Yugoslavia and with the establishment of an independent Slovene state in 1991. The post-socialist Slovene state dismissed self-management as a non-functional 'survival of socialism'. The Western type of representative democracy was introduced as a formal political system. Democracy has been redefined and reorganized from direct democracy to representative democracy. Representative democracy has been equted with 'Democracy' itself. Direct democracy was positioned as non-democracy.

Parts of Slovene post-socialist society accepted this redefinition. However, many of Slovenes never did.

\section{The Primary Characteristics of Native Slovene Democracy}

As mentioned, Slovene native democracy had a set of distinctive characteristics which defined it over a long historical period from the $6^{\text {th }}$ century to the end of socialism in 1991.

The first characteristic is that native Slovene democracy was direct democracy. In rare situations some elements of representative democracy were part of native Slovene democracy (kosezi’s veča in Old-Slovene society, the delegate system in socialist self-management), but the majority of decisions were not accepted in that way. The essence of self-management was direct democracy: "In self-management it was the people who decided about all aspects of their life" (Field material, professor, March 2011). And: "Self-management was about direct decisions, accepted by

Godina 1998; Heuvel \& Siccama 1992; Jović 2003; Kardelj 1955, 1957, 1977, 1980; Lampe 1996; Meier 1999; Pirjevec 2011; Ramet 1992, 2006; Štaubringer 1980; Ustava SFRJ 1976; Županov 1977. Data collected through observation with participation prove that inhabitanits of contemporary postsocialist Slovenia still remember several deficiencies of self-management, but they generally stressed the positive aspects of self-management as more important (Godina 2016). This attitude toward selfmanagement is in accordance with Pine's (2007: 111) conclusions about social memory: "Social memory is selective and contextual. When people evoked the 'good' socialist past, they were not denying the corruption, the shortages, the queues and the endless intrusions in infringements by the state; rather, they were choosing to emphasize other aspects: economic security, full employment, universal healtcare and education". This practice can be understood as a special kind of nostalgia for socialism, which - as with all practices that form part of this nostalgia - raise several questions about how one understands socialism in a given ex-socialist country.

Moreover, in professional discussions, the question how to understand Yugoslav political system still remains open. In several texts, Flere and Klanjšek (2014, 2017:57-67, 2019a:97-125, 2019b:91-115) prove that socialist Yugoslavia did not fulfil elements for totalitarian system: "from the middle of the $60 \mathrm{~s}$, millions of copies of religious newspapers were published and economic enterprises operated beyond the state command economy. In addition, the republics were largely autonomous players and catered for their own interests. Although Tito's cult was promoted, his power was limited by the federal nature of the state. Neither any other

elements of totalitarianism could be found"(2014:237). They suggest that the "Yugoslav political system could be nominated an authoritarian consociation, as of the middle $1960 \mathrm{~s}$ on, given the absence of a better fitting designation" (2019b: 109). 
workers. In our factory workers made all the important decisions" (Field material, unemployed textile worker, April 2009).

Direct democracy allowed members of the actual social community to participate in decision making process about all problems of their everyday lives. This participation was expected, and, as already described, in many situations also necessary (for example in huba village). Under self-management, this obligation was asserted by the Yugoslav constitution (see Ustava SFRJ 1974). Not to participate in this process was understood as negative behaviour or even as anti-social behaviour: "Only those who were not interested in the factory and the interests of the factory failed to participate in self-management. But they were the minority. And we treated them as weird. The majority participated. We wanted to have control over things" (Field material, unemployed worker, June 2010).

The fact that Slovene native democracy was direct democracy is connected to the second crucial characteristic of Slovene native democracy: native Slovene direct democracy included every member of the group in the processes of decision-making, regardless of their wealth or gender. This characteristic substantially separated Slovene native democracy from the ancient Greek version, in which gender and wealth were presuppositions for participation in democratic decision-making processes. If Greek democracy in the polis was exclusive, Slovene native democracy was inclusive. This characteristic was the bases for the previously mentioned principle that veča always met in the open. This allowed everyone to participate in the decision-making process (Maček 2007: 43-44; Vilfan 1961: 63). An enclosed space might have prevented this. In Slovene feudal society, closed veča could not make valid decisions (Maček 2007: 43-44; Vilfan 1961: 63). Later, such večas were proclaimed illegal (Maček 2007: 43-44; Vilfan 1961: 63).

During socialist self-management, meetings of workers were organized in the biggest factory hall or other appropriate part of factory; to prevent someone from participating in the decision making process was understood as manipulation. "Sometimes the director and his team didn't want us workers to accept certain decisions, for example about extraprofit, what to do with it, to buy new machines or to use it for our salaries ... They didn't want to organize workers' meetings. That was a clear manipulation. If anyone tried to prevent us workers from participating in the decision-making process, we understood that as manipulation and as a misuse of power" (Field material, an unemployed worker, November 1999).

The third crucial characteristic of Slovene native democracy is that this democracy was first of all economic democracy, i.e. a democracy through which the economic problems of members of a given social group were solved. This dimension of Slovene native democracy became dominant especially in village democracy, because "assemblies of villagers of one village...were limited to the economic affairs of the village" (Vilfan 1980a: 40). Village democracy was not concerned with political questions.

Also self-management was primarily economic democracy (see Kardelj 1977, 1980), which practiced the decision-making process especially when work was in question. Although self-management was also practiced in local communities where 
people resided, self-management in production in factories, was understood as the core aspect of self-management (see Kardelj 1977, 1980; Ustava SFRJ 1974).

The fourth key feature of the Slovene native democracy has been its focus on survival. Organization of economic production in village communities and later in socialist factories had a clear aim: to organize economic production in such a way, to facilitate survival of the members of community. This aim connects the Slovene economic democracy directly to the domestic mode of production, which in Sahlins' (1972) opinion, is the characteristic mode of production for agrarian societies.

And Slovene society was during the most part of its history an agrarian society (Maček 2007). The common goal of all members of the homestead, organized around huba, was to ensure the survival of all members of the household by pooling each member's work and products. Homesteads operated on the principle that each member contributed according to his or her ability and received according to his or her needs (Sahlis 1972: 124). This principle was valid for those who worked at the homestead as well as for those who were unable to work; otherwise, children, old people and the sick members of a household would not have survived.

Moreover, in socialist self-management, the survival of all workers and all members of Yugoslav society was the basic aim of economic organization. The economy should guarantee work, salaries, residence and pensions for all Yugoslavs, for those who were able to work and for those who were unable to work or didn't work. The Yugoslav socialist economy was organized in accordance with the social principle of the survival of all members of the socialist community, not in accordance with profit. This aspect of the Yugoslav socialist economy was strongly criticized, especially by economists. A common criticism was that the Yugoslav socialist economy was not economically rational. That was true: the aim of the Yugoslav socialist economy was not economic rationality, but social rationality, not profit, but the surviving of all members of the Yugoslav socialist community. The survival of all members of the community was the ultimate aim of all activities in Yugoslav society, at all levels of social and economic organization, from the state to each individual factory.

In factories this aim was realized through the institutions of guaranteed work and salaries. A job was almost impossible to lose. Moreover, a minimum salary was guaranteed to all, independent of the quantity and quality of work. In a socialist factory, just as in a village household, it was membership and not the quantity or quality of work that was the precondition for survival. All processes in socialist factories were organized in such a way that survival of all workers was guaranteed. The same was also true for the direct democracy of the self-management system.

The fifth key feature of native Slovene direct democracy was that it was a system of negotiation and decision-making, tending to seek and build a consensus, not to overrule anyone. This characteristic substantially separated Slovene native democracy from both ancient Greek and Western democracy. As a characteristic of Slovene native democracy, consensus was linked to the fact that all members of a village community had to coordinate when they would simultaneously perform the same work on the land. This was the precondition that allowed cultivation of one's 
land without destroying the crops of others. To achieve this way of cultivation, it was necessary to come to a consensus. A majority vote did not suffice.

As the final crucial characteristic of Slovene native democracy, we should emphasise the fact that the decision making process in Slovene native democracy was permanent. Processes of decision making, especially those which were connected to the organization of work, formed a permanent part of social life in a village community. Some of them were practiced daily. Moreover, self-management was a permanent process of decision making, which was always activated when management or/and workers wanted to discuss problems and accept decisions: "We decided about problems when it was needed. We had regular meetings of the worker's assembly, but if needed, we also had other meetings" (Field material, unemployed worker, June 2008).

\section{Why Do Slovenes Dislike Imported Western Democracy?}

These six characteristics of native Slovene democracy prove that there do exist several important differences between native Slovene democracy and the Western democracy, that was imported into post-socialist Slovenia.

Having in mind the basic characteristics of Slovene native democracy, it is clear why the import of Western parliamentary democracy produced several misunderstandings and problems in Slovene postsocialist society. Western parliamentary democracy is organized around principles different from native Slovene democracy; its logic and practice of decision making are in many respects in contradiction of, even in conflict with the logic and process of decision-making process in native Slovene practice of democracy. Those differences crucially determine the negative evaluation of postsocialist Slovene democracy by Slovenes.

The first crucial difference lies in the fact that Western democracy is representative, not a direct democracy. We have already mentioned that native Slovene democracy also had elements of representative democracy (kosezi s veča, the delegate's system); however, these elements were neither the most important elements of Slovene democratic practices, nor crucial elements of that democracy. Over the course of Slovene history, the representative principle was understood as secondary and evaluated as a subordinated democratic practice to direct democracy.

It is interesting that Kardelj (1977: 145-166) explicitly tried to defend the delegatski sistem as a representative element of self-management; with direct democracy, he didn't have this type of problem. He insisted on the position that the delegate system was not only a system of government and power (1977: 146). He stressed explicitly that such an understanding of the delegate system was wrong, because it ignored the fact that the delegate system was also "an exponent of selfmanagement communities and their self-managing process of decision making" (1977: 146). He stressed that "for further integration of self-management into a homogeneous social system, both components of the delegate system ought to be developed" (1977: 146). This means that in his opinion even in the delegate system 
as a representative element of self-management, elements of the self-managing decision-making process (i.e. elements of direct democracy) should have been reinforced (1977). Or, to put it another way: the representative aspect of selfmanagement needed as much correction by direct democracy as possible. What type of democracy was in that perception evaluated as positive, is clear.

Such evaluation is still present in post-socialist Slovene society. My informants regularly evaluate these two types of democracy in this way: "If democracy is a government of people, what we have now in Slovenia, is not a democracy. In democracy, decisions are made by people" (Field material, retired worker, September 2010). And: "Parliamentary democracy is just an image of democracy" (Field material, May 2013). Or: "The Parliament is just a masquerade!" (Field material, unemployed textile worker, February 2011).

From the native Slovene perspective, representative type of democracy is problematic because this type of democracy disallows direct participation of people in the decision making process. "Today we cannot decide about anything. All decisions are accepted by Parliament. This is not a democracy" (Field material, employed worker, May 2010). And: "There was more democracy during socialism. We could make decisions about everything. We had influence" (Field material, retired women, November 2009).

Among Slovenes, the absence of direct democracy is understood as proof that contemporary Slovene postsocialist society has no 'true' democracy or even no democracy at all.

The second important difference between native Slovene democracy and Slovene post-socialist democracy is connected with the question of who participates in the process of decision making. In native Slovene democracy all members of the social community participated in the decision making process. In self-management, such participation was not only a right, but also an obligation. This characteristic of native Slovene democracy is also blocked in Slovene postsocialist democracy. As in all parliamentary democracies, also in the Slovene parliamentary democracy it is members of Parliament who participate in the process of decision making. However, in the Slovene native understanding of democracy, power belongs to the people, to all members of the social community. If an institution takes this power from people, this is not understood as representation, but as stealing. That practice is understood by Slovenes as 'stealing power from people by Parliament': “Through parliament they stole power from people" (Field material, retired worker, September 2010). Those who stole a power from the people are the Parliament and members of Parliament.

This perception clearly evaluates 'people' as positive political carriers of power, and the Parliament and members of Parliament as negative carriers of power. Such an evaluation is connected with a de-legitimization of Parliament, members of Parliament and the whole system of representative democracy in postsocialist Slovenia, as well as with the social construction of mistrust (Giordano \& Kostova 2007), which is a characteristic process in postsocialist Slovenia.

On the other hand, this understanding is connected with the positive evaluation of socialism as a system in which democracy did exist: "We had more democracy 
under socialism" (Field material, retired worker, September 2010). "We had more democracy under socialism than we have now" (Field material, unemployed textile worker, May 2012). This positive evaluation of socialism can also be understood as a special form of nostalgia for socialism (see Berdahl 1999; Hann \& Hart 2011: 132-133).

For Slovenes, the next problematic dimension of imported Western democracy lies in the fact that decisions are taken by majority vote. This characteristic of Western democracy is in clear contradiction with the native Slovene way in which decisions were and should be accepted, namely, by consensus. Among Slovenes, consensus is understood as a democratic practice, and overruling is understood as a non-democratic practice. The reason for this understanding lies in the already mentioned fact that in native Slovene democracy practiced in huba village, overruling was not a practice through which the cultivation of huba land was possible. For this cultivation, consensus was needed from all famers and members of the village community. Explicitly, the social practice of cultivation of huba land was possible only if this practice was in accordance with the opinions and interests of all the farmers and members of the village community. Nobody's interests and opinions should be ignored.

In postsocialist imported Western representative democracy, the opinions and interests of many people - some of my informants indicate the of majority of people - are ignored. Some options and opinions are regularly overruled, a practice which among Slovenes is understood not as democracy, but as the inability of the overruled to realize their interests etc., i.e. as an absence of democracy. Those who practice it are understand as non- democrats: "People who are not in power, who don't have a good background, they don't have any voice, any power. They are regularly overruled. Nobody ask them what they need, what they want. They don't exist in this society. This is not democratic. In democracy everyone is important, everyone has a voice" (Field material, employed worker, July 2012).

An illustrative example of that understanding of democracy happened in April 2016. The Leftist party in the Parliament, called The United Left, had a congress where they discussed the possibility of formally uniting the four political parties which were elements of The United Left. The leader of The United Left, young, very popular Slovene politician named Luka Mesec, also a member of Parliament, agreed with the idea of formal unification of four separate political parties into one political party. However, many members of these four parties didn't agree with the idea of unification. The same was true for the leaders of one particular party that was part of The United Left. Discussion at the congress didn't result in consensus. At the end they decided to vote. The majority supported the idea of formal unification. Those who were overruled attacked Mesec as being non-democrat, i.e. as a politician, who was not a socialist (if he had been a socialist, he would have insisted on consensus and democracy); they accused him of ignoring the opinion of the base (baza) etc. According to the standards of native Slovene democracy, Mesec had made a mistake: he should have insisted on discussion as long as necessary to produce consensus. Only with consensus could he have authorization for formal unification of the political 
parties that comprise The United Left. Without this consensus, his insistence was seen as an undemocratic practice. He took even one step further in delegitimizing his position: on TV he explained that he had support for his idea about formal unification of the parties by a majority of voters, who belong to The United Left, and added: "This is a normal practice in representative democracy!" The sentence with which he publicly defined himself as a person who does not understand what the Slovene understanding of democracy is.

The next characteristic of imported Western democracy that is criticized among Slovenes concerns the fact that this democracy excludes workers from the decision making process: "Workers don't get the chance to accept decisions. That is absolutely wrong" (Field material, an unemployed worker, April 2009). And: "Today all decisions are accepted either by Parliament or by management. They don't know anything about our problems, our life. Their decisions are wrong, unrealistic. For example, their evaluation of the minimal costs of surviving in Slovenia - nobody can survive on the state support for unemployed workers" (Field material, employed worker, November 2011).

Also missing is the possibility for people to accept decisions about all aspects and problems of their lives. In post-socialist Slovene democracy, people can vote only on decisions about who will over the next four years take decisions in their name. People can't accept these decisions by themselves. This inability is understood as one of the most crucial mistakes of Slovene post-socialist democracy: "We cannot decide on anything. We can only participate in voting. This is not a democracy" (Field material, employed intellectual, October 2011).

From the native Slovene point of view, it is also very problematic that imported Western democracy does not solve the problems of Slovene citizens that affect their everyday lives, their survival. "The system we have doesn't work. It doesn't solve the problems of the people" (Field material, employed male engineer, March 2008). And: "Who is addressing the problem that people don't have work? Nobody. And poverty? Nobody..." (Field material, employed male engineer, March 2008). Or: "If you watch the 3rd Chanel on TV, it is obvious that they are not interested in solving people's problems “23 (Field material, retired clerk, August 2012 ).

Another important difference between Slovene native democracy and imported Western democracy lies in the fact that native Slovene democracy in all its variants was an economic, and not a political democracy. Regular negative comments on and evaluations of imported Western democracy concern the fact that post-socialist Slovene democracy doesn't solve the economic problems of Slovenes: "They discuss and solve some abstract political problems. But nobody solves the basic economic problems of Slovenes and the Slovene state" (Field material, retired bank clerk, August 2013).

The last problematic aspect of Slovene post-socialist democracy is that this democracy prevents people from participating permanently in the decision making process. In Western democracy citizens can participate in the decision making process

\footnotetext{
${ }^{23}$ On Channel 3 of TV Ljubljana, sessions of the Slovene Parliament are broadcast.
} 
only periodically, at elections. This characteristic of Slovene postsocialist democracy is also in conflict with native Slovene democracy, in which people participate regularly in decision-making process, even on a daily basis. In postsocialism, however, participation is limited to elections, which take place only once in four years. What people have in contemporary post-socialist Slovene democracy is a temporary possibility to choose a person who will decide in their names over the next four years. This type of participation by voters in the decision making process is understood among Slovenes as the key proof that Western democracy is not democracy: "That you can decide only once in four years - this is not a democracy" (Field material, employed engineer, March 2012). "This is not a democracy. This is a farce of democracy. We can decide only once in four years" (Field material, retired clerk, August 2012). "We can decide only once in four years, and they in the Parliament can do what they want" (Field material, retired clerk, August 2012).

From Slovene native perspective, democracy means the regular opportunity to participate personally in the decision-making process. What people have in contemporary postsocialist Slovene democracy is the occasional opportunity to choose a person who for the next four years will decide in their names. As long as this other person participates in decision-making process instead of them, the electors cannot participate in the decision-making process. From the perspective of native Slovene democracy, such a situation is seen as clearly non-democratic. Several things are missing: first, the regular opportunity to participate in decision-making process; second, participation of all members of the social community in the decision-making process; third, consensus as the way of finding solutions; and fourth, the chance for people to make decisions about all aspects and problems of their lives.

On the other hand, these characteristics of Slovene postsocialist democracy are connected with the statement by many Slovenes that Members of Parliament, who are in a positon to vote on solutions, use this power to validate solutions which are in their interest, not in the interest of the people who elected them. This means that people lack the power to approve the solutions they are interested in, and Members of Parliament are in power to misuse their power. Slovene people regularly report that Members of Parliament misuse their power to approve solutions which are in their interest only: "Members of Parliament have no idea about democracy. They are supposed to contact the people who elected them, they are supposed to represent their problems, interests...But they only take care of themselves. This is not democracy" (Field material, unemployed textile worker, November 2011).

Such evaluations prove that among Slovene voters, the Slovene parliament is understood as a homestead unit, as a unit that functions in accordance with homestead principles (see Sahlins 1972): its concern is the survival of its own members, without regard to what this means for the rest, who are not members of this 'estate'. This is the Slovene Parliament, as seen by numerous citizens of Slovenia. Unfortunately, analysis of political practices in the Slovene Parliament proves these evaluations and opinions in many situations to be correct.

Bearing in mind the basic characteristics of Slovene native democracy, it is clear why implementation of Western parliamentary democracy produced problems in Slovene post- 
socialist society: Western parliamentary democracy is organized around principles distinct from those of native Slovene democracy. The logic and practice of decision making in the two types of democracy are in many respects in contradiction, even in conflict.

\section{Conclusion}

In our analysis of the political heritage in Slovene postsocialism, insistence on the significance of pre-postsocialist history, stressed by several anthropologists of postsocialism, proved to be correct (see Abrahams 1996; Bridger \& Pine 1998; Giordano \& Kostova 2007; Godina 2016; Hann 2007; Humphrey 1998, 2002, 2007; Kalb 2007; Kaneff 1996, 2002; Lampland 2007; Pine 2007; Verdery 1993, 1996, 1999, 2007). We have established that the native Slovene type of direct democracy had been part of Slovene social organization since the Old-Slovene society. The same is true for the most important characteristics of Slovene direct democracy. It is true that those characteristics, together with native Slovene direct democracy, are among the basic characteristics of Yugoslavian socialist self-management. However, these were not new inventions. What was new was the form in which the political heritage of direct democracy was practiced during Yugoslavian socialism (delegate system, delegates, system of socialist self-management etc.).

The same is also true for contemporary Slovene postsocialist society. The current dissatisfaction with the Slovene parliamentary system and the Slovene system of representative democracy stems from the fact that the contemporary Slovene political system thwarts possibilities for practicing direct democracy as one of the most important political heritage of Slovenes. As my field material additionally proves, this obstruction is connected not only to dissatisfaction with the political system - so characteristic of Slovenes - but also to a new delegitimization of the contemporary Slovene political system and ultimately to an increasing refusal of political participation among Slovenes in Slovene postsocialist society and with a positive re-evaluation of Yugoslav socialism.

On the other hand, in the last decade, reintroduction of direct democracy was proposed by different groups, which are not satisfied with Slovene postsocialist democracy. Among them are The United Left, several civic initiatives and members of uprising movement in Maribor. Different forms of direct democracy have been introduced in different factories and entertainments in Slovene ownership which are today recognized as examples of good economic practice (see Vaupotič, Mladič et al. 2015). In the year 2015, Slovene Economic Chamber had organized a conference about reintroduction of direct democracy in form of direct economic democracy in economic productive units (see Vaupotič, Mladič et al. 2015).

There also exist examples of reintroduction of direct democracy in local communities where people live. Most active initiatives are present in Maribor, the town which was in 2013 the centre of Slovene uprisings against the Mayor of Maribor Franc Kangler and the Prime Minister Janez Janša. On invitations for meeting in local community in Maribor there wrote: "We are not stupid. We are not dreamers. We are upraised, awoken, conciseness people who want rights and better lives, who 
want democracy every day, not only on elections!" (Godina 2016: 250).

The lesson is clear: what is going on in Slovenia is a spontaneous reintroduction of direct democracy as a form of political heritage. Through this process Slovenes realize an indigenization of imported Western representative democracy. They teach formal political institutions the lesson that only with the recognition of political heritage and the reform of the political system to incorporate Slovene direct democracy into the contemporary Slovene political system, can the most important problems of contemporary Slovene political system be solved. Slovene postsocialist democracy cannot be successful without this recognition, but only with the political heritage from the pre-socialist (and also socialist) past; not without but with native Slovene direct democracy.

Whether such a redefinition of the Slovene political system should be understood as the re-traditionalization of Slovene society, or as indigenization of an imported Western solution, is a question we cannot discuss here. It could plausibly be the first or the second explanation, or even more probable, a unique combination of both processes. What is important is that productive change in Slovene postsocialist society and in Slovene postsocialist democracy is not possible without the incorporation of Slovene political heritage into contemporary and future Slovene society.

\section{References}

Abrahams, Ray, ed., 1996. After Socialism: Land Reform and Social Change in Eastern Europe. Oxford: Berghahn.

Adrić, Iris, Arsenijević, Vladimir. \& Matić Đorđe. (2000). Leksikon YU mitologije. Zagreb \& Beograd: Rende, Postscriptum.

Sejdić and Finci v. Bosnia and Herzegovina. (2009). European Court of Human Rights. Online at https://hudoc.echr.coe.int/eng\#\{\%22itemid\%22:[\%22001-96491\%22]\}. Accessed: [February 10, 2019]

Allcock, John B., Horton, John J. \& Milivojevic, Marko (eds). (1992). Yugoslavia in Transition. London: Berg.

Banac, Ivo. (1984). The National Question in Yugoslavia. Itaca, NY: Cornell University Press.

Berdahl, Daphne. (1997). Where the World Ended: Re-unification and Identity in German Borderland. Berkeley: University of California Press.

Berdahl, Daphne. (1999). „(N)Ostalgie for the Present: Memory, Longing, and East German Things“. Ethnos 64(2), pp. 192-211.

Bilanžić, Dušan. (1985). Historija SFRJ. Zagreb: Školska knjiga.

Blaznik, Pavle. (1970). Poljska razdelitev. In: Blaznik, Pavle, Grafenauer, Bogo \& Vilfan, Sergij (eds). Gospodarska in družbena zgodovina Slovencev. 1. zvezek: Agrarno gospodarstvo. Ljubljana: DZS, pp. 185-196.

Blaznik, Pavle, Grafenauer, Bogo \& Vilfan Sergij (eds). (1970). Gospodarska in družbena zgodovina Slovencev. 1. zvezek: Agrarno gospodarstvo. Ljubljana: DZS.

Blaznik, Pavle, Grafenauer, Bogo \& Vilfan Sergij (eds). (1980). Gospodarska in družbena zgodovina Slovencev. 2. zvezek: Družbena razmerja in gibanja. Ljubljana: DZS. 
Bowman, Glenn (ed). (1993). Antagonism and Identity in Former Yugoslavia. Journal of Area Studies 3.

Bridger, Sue, \& Pine, Frances (eds). (1998). Surviving Postsocialism: Local Strategies and Regional Responses in Eastern Europe and the Former Soviet Union. London: Routledge.

Burg, Stiven L. (1983). Conflict and Cohesion in Socialist Yugoslavia. Princeton: Princeton University Press.

Burgess, Robert G. (1990/1984/). In the Field: An Introduction to Field Research. New York: Routledge.

Caharijas, D. 2016. »Po četrt stoletja razočarani nad državo.« Dnevnik 20.6.2016, p.1.

Center za raziskovanje javnega mnenja. (2013). Politbarometer, 1/2013. Available at: https://www.ip-rs.si/fileadmin/user_upload/Pdf/razno/politbarometer_1-2013.pdf. [Accessed: Ferbrauy 09, 2019]

Center za raziskovanje javnega mnenja. (2014). Politbarometer, 6/2014. Available at: https://www.iprs.si/fileadmin/user_upload/Pdf/razno/politbarometer_1-2013.pdf. [Accessed: February 10, 2019]

Cohen, Lenard. J. (1995). Broken Bonds: Yugoslavia's Disintegration and Balkan Polities in Transition. Boulder, CO: Westview Press.

Dedijer, Vladimir, Božič, Ivan, Čirković, Sima \& Ekmečić, Milorad. (1972). A History of Yugoslavia. New York.: McGraw Hill.

Đorđević, Jovan (ed.). (1966). Mala politička enciklopedia. Beograd: Savremena administracija.

Flere, Sergej \& Klanjšek, Rudi. (2014). “Was Tito’s Yugoslavia totalitarian?”. In: Communist and Post-Communist Studies 47, pp. 237-245.

Flere, Sergej \& Klanjšek, Rudi. (2017). Da li je Jugoslavija morala da umre. Beograd: Dan Graf.

Flere, Sergej \& Klanjšek, Rudi. (2019a). Analiza razpada Jugoslavije v luči nacionalizma, Maribor: Umiverzitetna založba.

Flere, Sergej \& Klanjšek, Rudi. (2019b). The Rise and Fall of Socialist Yugoslavia. Elite Nationalism and the Collapse of a Federation, Lanhm, Boulder, New York, London: Lexington Books.

Giordano, Christian \& Kostova, Dobrinka. (2007). „The Social Production of Mistrust“. In: C. Hann, ed., Postsocialism: Ideals, Ideologies and Practices in Eurasia. London, New York: Routledge, pp. 74-93.

Godina, Vesna, Vuk. (1998). Antropološke teorije. Ljubljana: FDV.

Godina, Vesna, Vuk. (1998). „The outbreak of nationalism on former Yugoslav territory: a historical perspective on the problem of supranational identity". Nations in Nationalism 4(3), pp. 409-422.

Godina, Vesna, Vuk. 2016(2014). Zablode postsocializma. Ljubljana: Beletrina.

Grafenauer, Bogo. (1970). „Poljedelski obdelovalni načini“. In: Blaznik, Pavle, Grafenauer, Bogo \& Vilfan, Sergij (eds). Gospodarska in družbena zgodovina Slovencev. 1. zvezek: Agrarno gospodarstvo. Ljubljana: DZS, pp. 225-250. 
Heuvel, Martin Van Den \& Siccama, Jan G. (eds.). (1992). The Disintegration of Yugoslavia. Amsterdam: Rodopi.

Hann, Chris M. (2001). „Farewell to the Socialist 'Other'“. In: Hann, Chris M. (ed.). Postsocialism: Ideals, Ideologies and Practices in Eurasia. London, New York: Routledge, pp. 1-12.

Hann, Cris M. \& Hart, Keith. (2011). Economic Anthropology. History, Ethnography, Critique. Cambridge: Polity Press.

Humphrey, Carolina. (1998). Marx Went Away - But Karl Stayed Behind. Ann Arbor: University of Michingan Press.

Humphrey, Carolina. (2002). The Unmaking of the Soviet Economy: Everyday Economies after Socialism. Ithaca, NY: Cornell University Press.

Humphrey, Carolina. 2007(2002). „Does the Category 'Postsocialist' still make Sense“. In: Hann, Chris (ed.). Postsocialism: Ideals, Ideologies and Practices in Eurasia. London, New York: Routledge, pp. 2-15.

Jović, Dejan. (2003). Jugoslavija - država koja je odumrla. Zagreb: Prometej.

Kalb, Don. (2002). „Afterword: Globalism and Postsocialist Prospects“. In: Hann, Chris (ed.). Postsocialism: Ideals, Ideologies and Practices in Eurasia. London, New York: Routledge, pp. 317-335.

Kaneff, Deema. (1996). „Responses to 'Democratic' Land Reform in a Bulgarian Village“. In: Abrahams, Ray (ed.) After Socialism: Land Reform and Social Change in Eastern Europe. Oxford: Berghahn, pp. 85-114.

Kaneff, Deema. (2002). Who Owns the Past? The Politics of Time in a 'Model'Bulgarian Villag. Oxford: Berghahn.

Kardelj, Edvard. (1955). Problemi naše socialistične graditve, Vol. III. Ljubljana: DZS.

Kardelj, Edvard. (1957). Razvoj slovenskega narodnega vprašanja. Ljubljana: DZS.

Kardelj, Edvard. (1977). Smeri razvoja socialističnega samoupravljanja, Ljubljana: Komunist.

Kardelj, Edvard. (1980). Self-management Planning, second ed., Sarajevo, Beograd: Aktuelna pitanja socijalizma.

Kideckel, David A. (1999). „Storm and Stasis: the Paradox of Labour in post-socialist Romania“. Emergo: Journal of Transforming Economies and Societies 6(2), pp. 24-46.

Kideckel, David A. (2002) 2007. „,The Unmaking of an East-Central European Working Class“. In: C. Hann, ed., Postsocialism: Ideals, Ideologies and Practices in Eurasia. London, New York: Routledge, pp. 114-133.

Kideckel, David A. (2008). Getting by in postsocialist Romania: Romanian villagers to the revolution and beyond, Bloomington: Indiana University Press.

Lampe, John. (1996). Yugoslavia. Twice There Was a Country. Cambridge: Cambridge University Press.

Lampland, Martha. (2002). „The Advantages of Being Collectivized: Cooperative Farm Managers in the Postsocialist Economy“. In: Hann, Chris (ed.). Postsocialism: Ideals, Ideologies and Practices in Eurasia. London, New York: Routledge, pp. 31-57.

Maček, Jože (2007). Na zemlji domači. Celje: Celjska Mohorjeva družba.

Makarovič, Marija. (1982). Strojna in Strojanci. Narodopisna podoba koroške hribovske vasi. Ljubljana: Mladinska knjiga. 
Meier, Viktor. (1999). Yugoslavia: A History of its Demise. New York: Routledge.

Pine, Frances. 2007(2002). „,Retreat to the Household? Gendered Domains in Postsocialist Poland“. In: Hann, Chris (ed.). Postsocialism: Ideals, Ideologies and Practices in Eurasia. London, New York: Routledge, pp. 95-114.

Pirjevec, Jože. (2011). Tito in tovariši. Ljubljana: Cankarjeva založba.

Ramet, Sabrina. (1992). Nationalism and Federalism in Yugoslavia. Bloomington: Indiana University Press.

Ramet, Sabrina. (2006). The Three Yugoslavias. State-building and Legitimation, 19182005. Indianapolis, IN: University Press.

Sahlins, Marshall. (1972). Stone Age Economics. New York: Routledge.

Sahlins, Marshall. (1994). „Goodbye to Tristes Tropes: Ethnography in the Context of Modern World History“. In: Borofsky, Robert (ed). Assesing Cultural Anthropology. New York, etc.: McGraw-Hill, pp. 377-395.

Štaubringer, Zvonko. (1980). Plamenica iz Kumrovca. Ljubljana: DDU Univerzum.

Ustava SFRJ. (1976) Ljubljana: Komunist.

Vaupotič, Karmen, Mladič, Mirjana, Lužar Šajt Dušanka, et all. (2015). S sodelovanjem do zaupanja in uspešnega poslovanja. Maribor: DEMINE.

Velikonja, Mitja. (2008). Titostalgija: študija nostalgije po Josipu Brozu. Ljubljana: Mirovni inštitut.

Verdery, Katherine. (1993). Transylvanian Villagers: Three Centuries of Political, Economic and Ethnic Change. Berkeley: University of California Press.

Verdery, Katherine. (1996). What Was Socialism and What Comes Next?, Princeton: Princeton University Press.

Verdery, Katherine. (1999). The Political Lives of Death Bodies: Reburial and Postsocialist Change. New York: Columbia University Press.

Verdery, Katherine. 2007(2002). „Whither postsocialism?“ In: Hann, Chris (ed.). Postsocialism: Ideals, Ideologies and Practices in Eurasia. London, New York: Routledge, pp. 15-29.

Vilfan, Sergij. (1994). „Očrt slovenskega pravnega narodopisja“. In: R. Ložar, ed., Narodopisje Slovencev. Ljubljana: Klas, pp. 217-263.

Vilfan, Sergij. (1961). Pravna zgodovina Slovencev. Ljubljana: Slovenska matica.

Vilfan, Sergij. (1980a). „Soseske in druge podeželske skupnosti“. In: Blaznik, Pavle, Grafenauer, Bogo \& Vilfan, Sergij (eds.). Gospodarska in družbena zgodovina Slovencev. 2. zvezek: Družbena razmerja in gibanja. Ljubljana: DZS, pp. 9-74.

Vilfan, Sergij. (1980b). „Zemljiška gospostva“. In: Blaznik, Pavle, Grafenauer, Bogo \& Vilfan, Sergij (eds.) Gospodarska in družbena zgodovina Slovencev. 2. zvezek: Družbena razmerja in gibanja. Ljubljana: DZS, pp. 75-239.

Vilfan, Sergij. (1980c). „Kmečko prebivalstvo po osebnem položaju“. In: Blaznik, Pavle, Grafenauer, Bogo \& Sergij Vilfan (eds.) Gospodarska in družbena zgodovina Slovencev. 2. zvezek: Družbena razmerja in gibanja. Ljubljana: DZS, pp. 279-353.

Županov, Josip. (1977). Samoupravljanje i sociologija. Zagreb: Školska knjiga. 


\title{
О ИСТОРИЈСКИМ РАЗЛОЗИМА ЗА НЕЗАДОВОљСТВО СЛОВЕНАЧКОМ ПОСТСОЦИЈАЛИСТИЧКОМ ПРЕДСТАВНИЧКОМ ДЕМОКРАТИЈОМ У САВРЕМЕНОЈ СЛОВЕНИЈИ
}

\begin{abstract}
Сажетак: Текст представља анализу историјских разлога за незадовољство словеначком постсоцијалистичком представничком демократијом у савременој Словенији. Суштински разлог овог незадовољства лежи у чињеници да се Западна демократија у многим карактеристикама разликује од изворне словеначке демократије, која је била важан део словеначке друштвене организације од 6. века до краја социјализма. Анализа ће представити словеначку изворну демократију и њене најважније карактеристике и упоредити их са карактеристикама увезене Западне демократије. Анализа доказује да увезена Западна демократија пренебрегава најважније праксе и карактеристике словеначког политичког наслеђа које су из изворне словеначке перспективе повезане, чак изједначене са демократијом. То ствара неколико проблема, укључујући незадовољство словеначком постсоцијалистичком демократијом. У тексту ће се комбиновати историјска анализа и подаци прикупљени теренским радом у словеначком постсоцијалистичком друштву.
\end{abstract}

Кључне речи: Демократија, директна демократија, Западна демократија, постсоцијализам, Словенија 
